\title{
Ethnic penalties in graduate level over-education, unemployment and wages: evidence from Britain
}

Work, employment and society $0(0) \mathrm{I}-20$

(C) The Author(s) 2012 Reprints and permission: sagepub. co.uk/journalsPermissions.nav DOI: $\mid 0.1177 / 095001701245802$ | wes.sagepub.com

@SAGE

\author{
Anthony Rafferty \\ University of Manchester, UK
}

\begin{abstract}
Although access to higher education has helped many minority ethnic men and women improve their labour market position compared to prior generations or the less qualified, it remains unclear to what extent higher level qualifications facilitate an equalization of labour market outcomes with comparably educated white UK born men and women. This article critically examines ethnic differences in graduate level over-education, unemployment and wages as potential markers of discrimination or broader 'ethnic penalties', defined as the differences in labour market outcomes persisting after accounting for observable human capital and demographic characteristics. To estimate ethnic penalties a novel approach using covariate matching is applied. The findings reveal that despite their levels of educational attainment penalties persist among several minority ethnic groups. The implications of pre-labour market social disadvantages for explaining patterns of over-education are highlighted.
\end{abstract}

\section{Keywords}

discrimination, employment gaps, ethnic gaps, ethnicity, gender, graduate employment, overeducation, over-qualification, unemployment, wage gaps

\section{Introduction}

Ethnic differences in occupational attainment, wages and unemployment cannot fully be explained by differences in human capital or demographic characteristics. The remaining unexplained component of such differences has been termed the 'ethnic penalty' in recognition that it may reflect discrimination but also other labour market disadvantages (Berthoud, 2000; Cooke, 2007; Heath and Cheung, 2006; McGinnity and Lunn, 2011).

\section{Corresponding author:}

Anthony Rafferty, European Work and Employment Research Centre (EWERC), Manchester Business School (East Building EI) University of Manchester MI5 6PB, UK.

Email: anthony.rafferty@manchester.ac.uk 
Studies of 'over-education' or 'over-qualification' suggest that a disproportionate number of minority ethnic men and women are employed in jobs which do not require their level of educational attainment both in the UK (Battu and Sloane, 2004; Lindley, 2009) and internationally (Chiswick and Miller, 2010; Green et al., 2007; Nielsen, 2011).

Ethnic differences in over-education are of interest to the study of ethnic penalties in that they could reflect discrimination or other barriers to the meritocratic matching of workers and jobs. Although sociological literatures examine ethnic differences in relation to occupational attainment or social mobility (Castilla, 2008; Khattab, 2009; Platt, 2007) much of the general over-education literature (see Burris, 2005; Vaisey, 2006) and research specifically on over-education and ethnicity is currently found within labour economics (Alpin et al., 1998; Battu and Sloane, 2002, 2004; Lindley, 2009). These studies furthermore tend to examine ethnic differences in over-education rather than ethnic penalties, as currently defined, and so do not provide full information on whether penalties persist after accounting for important compositional differences between ethnic groups such as levels of educational attainment.

The aims of the current article are consequently twofold. Firstly, through drawing on broader literatures on ethnicity and social disadvantage, a deeper theoretical understanding is sought of the relationship between ethnicity and over-education, critically examining whether between-group differences in over-education can be considered as markers of 'ethnic penalties'. Relevant explanations put forth for the occurrence of overeducation are critiqued. Based on a labour market discrimination account, patterns of over-education by ethnicity may reflect differences in skill underutilization due to discrimination in the labour market (Battu and Sloane, 2002). In contrast, according to a human capital or qualification heterogeneity explanation (Green and McIntosh, 2007), over-education does not necessarily solely reflect skill underutilization but wider differences in skills or the quality of education among individuals with equivalent level certificates, such as by qualification subject, grade achieved or institution attended. Differences in over-education between ethnic groups could therefore partly reflect aspects of education quality often not fully captured in survey data (Lindley, 2009: 81).

Both of these accounts as currently presented, it is argued, require broader sociological interpretation. Whereas a qualification heterogeneity based explanation needs further elaboration regarding the role social disadvantages related to ethnicity, social class and gender play in influencing patterns of educational and occupational attainment (Bradley and Healy, 2008; Collins, 2004) rather than just individual ability and rational choice (Chevalier, 2002, 2003), discrimination based accounts require more attention to how pre-labour market disadvantages may preclude the risk of over-education for those with no or low levels of educational attainment. Ethnic penalties in over-education therefore need to take into account variation in attainment between groups.

Ethnic penalties are consequently explored through a study of graduate (NVQ level 4 or above) over-education. The second and empirical aim of the article asks the question to what extent do penalties occur after accounting for compositional differences in human capital and demographic characteristics? With the exception of Alpin et al. (1998) and Wilton (2011), which draw contrasts between the white/majority and the entire "nonwhite' /minority ethnic population, little research has been conducted on ethnic differences in graduate level over-education. Although the expansion of higher education has 
been conceived as a mechanism towards greater social equality (Boliver, 2011) and has helped improve the employment position of many minority ethnic men and women compared to prior generations or the less qualified (Heath and Cheung, 2006; Platt, 2007), the extent to which such developments have facilitated an equalization of labour market outcomes to those of comparably educated white men and women remains unclear. The 'business case' for equality and diversity related to recruiting and retaining talent (Kirton and Green, 2010) may be stronger in higher skilled professions or higher qualifications may provide access to occupations with formalized career ladders, potentially mitigating against discrimination. Higher levels of graduate level over-education however could indicate minority ethnic men and women are disproportionately not gaining access to such occupations. Graduate level unemployment and wages are further examined to see whether ethnic penalties in these outcomes persist after accounting for degree subject, an important aspect of 'educational choice' in qualification heterogeneity accounts of overeducation and wage and unemployment gaps (Chevalier, 2002, 2003; Machin and Puhani, 2003; Ortiz and Kucel, 2008).

\section{Background}

Over-education occurs when people hold qualifications in excess of those required for their job. In comparison to those better matched to their job, research indicates overeducated people exhibit wage penalties (Hartog, 2000), lower job satisfaction (Battu et al., 1999) and higher turnover (Sloane et al., 1999). A large proportion of the literature on over-education has drawn on economic theory (Ortiz, 2011: 48). For example, overeducation has been considered in terms of temporary imbalances in supply and demand for qualifications (Freeman, 1976; Tsang and Levin, 1985), although its long-term persistence conflicts with this view (Chevalier, 2003), or 'qualification inflation', where employers upgrade job requirements when screening candidates in response to rising educational attainment (Brynin, 2002). It has also been considered as short term worker/ job skill mismatches that should decline over time through between-job transitions, although over-education is not necessarily short term or confined to recent labour market entrants (Battu et al., 1999; Sloane et al., 1999).

It is unclear how such accounts explain ethnic differences in over-education. In the absence of ethnicity related labour market barriers, the effects of changes in skill supply and demand, or short term job mismatches would be expected to be the same across ethnic groups. Barriers that prevent minority ethnic individuals obtaining employment matching their qualifications, however, could produce ethnic differences in overeducation. There is significant evidence of discrimination in the UK labour market which may differ by skin colour and ethnic, cultural or religious group (Khattab, 2009; Modood, 1997). Riach and Rich (2002), summarizing UK field studies, suggest that around 30-40 per cent of job applications made by minority ethnic candidates were refused on grounds of race/ethnicity. Where minority ethnic groups are only employed if they have greater qualifications than majority ethnic applicants (Alpin et al., 1998), are less likely to be promoted (Battu and Sloane, 2002), experience performance evaluation bias (Castilla, 2008) or are given less access to training, such practices could lead to higher levels of over-education. Over-education could also occur where minority ethnic applicants are 
overlooked during recruitment making some individuals more likely to accept jobs at a lower level than appropriate for their level of qualification or alternatively spend a longer time unemployed seeking better matched employment.

The study of ethnic penalties concerns the theoretical explanation of ethnic labour market differences in terms of whether these reflect unmeasured disadvantages such as discrimination or can be explained by observed factors such as human capital levels. If ethnic differences in over-education reflect discrimination they could indicate genuine differences in skill underutilization between ethnic groups. At the same time, whether measured over-education in the broader population reflects skill underutilization has been questioned. According to human capital or qualification heterogeneity accounts (Green and McIntosh, 2007), the occurrence of over-education is partly explained by differences in the quality of education or skills held by individuals who, based on the level of their highest qualifications or schooling, appear to have the same level of education. Labour market demanded skills or employability signals may vary within certificate levels in terms of qualification type, subject studied, grades obtained, institution attended and by wider employment experience (Dolton and Silles, 2001; Garcia-Espejo, 2005).

Between-group variation in such factors could contribute to ethnic differences in over-education (Lindley, 2009). In terms of high school achievement, black Caribbean, black African, Pakistani and Bangladeshi students on average score below the mean attainment of their white British peers, whereas Chinese, Indian and Irish students on average score higher (Department for Education and Skills, 2006). Other sources of disadvantage relate to the (perceived) value of overseas qualifications or English language ability (Dale et al., 2002). Regarding higher education, although overall minority ethnic groups are generally over-represented relative to their population proportion, except black Caribbean men (Barnard and Turner, 2011), generally they are less likely than white students to achieve first and upper second level class degrees and more likely to attend 'new' post-1992 universities (Connor et al., 2004). White students in the UK, however, are less likely than minority ethnic students to study traditional university degree subjects which confer specific professions such as medicine, dentistry and law, although differences also exist between minority ethnic groups.

As well as influencing the risk of over-education (Ortiz and Kucel, 2008) differences in degree subject or college major are also important to explaining graduate wage differences and unemployment risks (Chevalier, 2002; Connor et al., 2004). For example, in relation to the gender wage gap, Machin and Puhani (2003) found that 8-20 per cent of the gap for graduates (24-30\% of the total explained component) in the UK and Germany was attributable to differences in degree subject. Building on this work and broader research on wage and unemployment gaps related to ethnicity (Blackaby et al., 1999, 2002; Clark and Drinkwater, 2007; Connor et al., 2004; Leicht, 2008; Longhi and Platt, 2008) and gender (Blau and Khan, 2007; Grimshaw and Rubery, 2007; Olsen and Walby, 2004), differences in degree subject are also likely to contribute to graduate level ethnic wage and unemployment gaps.

In addition to finer grained variation in skills among equivalent level qualification holders, a further critical issue concerns how differences in overall levels of educational attainment influence patterns of over-education. Table 1 presents the incidence of overeducation by educational attainment level, using a common 'modal' measure (Battu and 
Table I. Over-education by highest qualification

\begin{tabular}{lllllr}
\hline Highest Qualification (NVQ level) & Level 4/5 & Level 3 & Level 2 & Level I & None \\
\hline Adequate & 44.8 & 15.6 & 24.6 & 4.0 & II.0 \\
Over & 29.7 & 44.3 & 14.5 & 11.6 & 0.0 \\
Under & 0.0 & 19.9 & 23.5 & 31.2 & 25.5 \\
\hline
\end{tabular}

Row percentages, UKLFS 2005-10 employed working age population.

Sloane, 2002; Lindley, 2009) indicating whether respondents hold qualifications above the modal level for their two-digit Standard Occupational Classification (SOC) occupation. Around 74 per cent of those who are defined as over-educated have post-secondary school qualifications (NVQ level 3 or above). One observation is that, given those with no or the lowest levels of educational attainment are typically the worst off (Barnard and Turner, 2011), over-education is likely to be a poor marker of disadvantage for the most vulnerable in the labour market. Ethnic penalties among those with fewer or no qualifications may be more likely to manifest as other outcomes such as job insecurity, unemployment or lower wages (see Leicht, 2008).

Levels of educational attainment furthermore vary significantly by ethnicity and gender. For example, whereas black African men and Chinese and Indian women are among the most likely to have degree level or above qualifications, Pakistani and Bangladeshi men and women are among the most likely to have no formal qualifications (Heath and Cheung, 2006). Prior studies examining ethnic differences in overeducation (Battu and Sloane, 2002, 2004; Lindley, 2009) do not explicitly seek to estimate ethnic penalties and so are limited in this respect by drawing comparisons across the entire qualification distribution. Where differences in educational attainment remain unaccounted for, the interpretation of findings on over-education becomes ambiguous. For example, is it a good thing that one group exhibits less over-education than another if this merely reflects that on average they have lower levels of educational attainment? Higher levels of qualification may further reflect minority ethnic groups over-compensating through educational attainment to mitigate against labour market disadvantages, meaning matched comparisons to comparably educated white UK born men and women reveal penalties concealed in simple overall comparisons.

The current article attempts to address these issues by specifically examining ethnic penalties (rather than just ethnic differences) using human capital and demographically matched comparisons. A focus is further placed on graduate level (NVQ level 4 or above qualifications) over-education. Although this approach helps restrict contrasts to similarly educated individuals, differences in graduate outcomes may still reflect qualification heterogeneity such as degree subject, institute attended or grade achieved. Qualification heterogeneity explanations put forth in the economics literature (Chevalier, 2003: 527), however, are problematic if applied to explaining ethnic differences in that they largely focus on differences in individual ability, preferences or rational choices regarding educational investment. A greater emphasis is consequently required on how ethnic variation in educational attainment reflects broader social disadvantages. Some older universities exhibit admission biases against minority ethnic students that persist 
after controlling for parental background, type of school background and attainment scores (Modood, 2004). Part of the reason some minority ethnic groups appear less likely to attend older institutions or are less likely to achieve first or upper second class degrees relates to their poorer A-level results (Connor et al., 2004). However this may partly be because of differences in the quality of pre-university education received. For example, minority ethnic students and individuals from poorer backgrounds are more likely to attend further education colleges than school sixth forms (Connor et al., 2004), which affects not only access to university but subsequent degree performance (Barnard and Turner, 2011; Richardson, 2008). Similarly, they are more likely to take alternative entry routes to university than A-levels or equivalent Scottish qualifications less preferred by more prestigious institutions (Purcell et al., 2009).

Socio-economic disadvantage and the greater risk of poverty among minority ethnic and immigrant households are additional factors that could contribute to attainment gaps such as through developmental or health impacts or a lack of economic or social resources (Barnard and Turner, 2011; Behtoui and Neergaard, 2010; Strand, 2011; Verhaeghe et al., 2012). However, although social class advantages and disadvantages remain important to explaining educational attainment and social mobility in the general population, they do not fully explain ethnic differences (Archer, 2011; Platt, 2007; Rothon, 2008). A number of studies show that 'black-white' attainment gaps in compulsory education persist after controlling for socio-economic background - other potential explanations cited include institutional racism within the education system or low teacher expectations (Strand, 2011). In addition to black Caribbean men, white men from disadvantaged socio-economic backgrounds are also among the most poorly represented in higher education (Barnard and Turner, 2011). Independent of ethnicity, men and women from socio-economically disadvantaged backgrounds are less likely to gain access to more prestigious higher education institutions even after accounting for prior educational performance (Boliver, 2011).

Gender is also important in explaining ethnic differences in qualification heterogeneity. Black Caribbean girls for example generally perform better in their GCSE high school qualifications than boys do (Connor et al., 2004; Strand, 2011). In terms of choice of higher education institution, Connor et al. (2004) found that Muslim women were over twice as likely as Muslim men to state family influence as reason for their selection, with proximity to family home important to family considerations. Choices of educational vocational pathways further differ by gender within ethnic groups. For example, black Caribbean women are concentrated in health and social care, although this may partly reflect historical patterns of immigration and occupational settlement or discriminatory barriers towards shifting occupations (Bradley et al., 2007; Smith, 2002).

Ethnicity, gender and social class when taken together therefore provide a more nuanced picture of ethnic differences in labour market outcomes, interrelating in varying ways both between and within ethnic groups and shaped by the material and cultural contexts in which individuals exert agency towards socio-economic goals (Carter and Virdee, 2008; Platt, 2007). Intersectional perspectives (Browne and Misra, 2003; Collins, 2004; see also Walby et al., 2012) in this respect consider how such dimensions, as socially constructed categories, interact to form patterns of power, privilege and disadvantage, related to access to productive or social resources (Bradley 
and Healy, 2008) and pervasive across both public and private spheres. Such accounts also hold relevance to explaining ethnic differences in graduate level employment. Intersections between gender and ethnicity rather than being additive may create unique or multiple forms of discrimination or disadvantage (Bradley and Healy, 2008; Browne and Misra, 2003). For example, prejudices against women in management or professional roles (Bolton and Muzio, 2008) can be reinforced by the stereotype that 'black people can't manage', whereas stereotypes regarding Asian women not being career orientated may further hamper employment advancement (Botcherby, 2006; Bradley and Healy, 2008).

Within the family context, women face additional employment constraints related to cultural practices surrounding gender roles, marriage, fertility and family size, although diversity both between and within ethnic groups should not be overlooked (Dale et al., 2002, 2008). In the case of Pakistani and Bangladeshi women, Bradley et al. (2007) found that some husbands may place restrictions on employment if it is not seen as compatible with household responsibilities (also see Cooke, 2007), whereas black Caribbean women have a higher rate of lone parenthood and are more likely to be employed full time. For some Pakistani and Bangladeshi women the cultural expectation or preference to live at home prior to marriage or maintain proximity to the parental or marital home may affect geographical mobility (Connor et al., 2004), potentially restricting job search area. Geographical constraints (Johnston et al., 2010) or a lack of social networks (Yeandle et al., 2006) could contribute to labour market penalties, although Battu and Sloane (2002) found that living in a ward with a high level of unemployment was not predictive of an increased risk of over-education.

\section{Methods and data}

Using the UK Labour Force Survey (UKLFS) the rationale of the method is to identify gender specific comparison groups from the white UK born majority sample, matched in their observable characteristics to the minority ethnic samples in the survey. The outcomes of these groups can be compared and the remaining differences after matching taken as the 'ethnic penalty'. This is expressed as the average treatment effect for the treated (ATT) (see Sekhon, 2009) indicating the difference between the average of an outcome for a given minority ethnic group to that which they would exhibit if members of the British born white majority as estimated from the comparator group. The outcomes considered are whether or not respondents work in a SOC (HE) (Elias and Purcell, 2004) graduate occupation ( $1=$ yes, $0=$ no), are unemployed $(1=y e s, 0=$ no) and hourly wage rate. For the first two outcomes, the ATT multiplied by a hundred gives the percentage difference between the minority ethnic and matched comparison group, whereas for the wage estimates the ATT expresses hourly wage rate differences.

The SOC (HE) classification of graduate jobs is comparable to a combination of 'realized match' and expert assessment (Chevalier, 2003: 514) measures of over-education, combining statistical information regarding concentrations of graduates within occupations with job analysis data on job descriptions and qualification requirements (Elias and Purcell, 2004). The SOC (HE) identifies four categories of graduate occupations, two of which consist of occupations for which employers typically require a degree, these being 
'traditional' graduate occupations (e.g. solicitors, doctors, scientists, lecturers and secondary school teachers) and 'modern' graduate occupations. The latter group represents newer professions, which graduates have been entering since the expansion of higher education in the 1960s (e.g. senior managers in large organizations, IT professionals and primary school teachers). A third category, 'new graduate jobs,' represents occupations where graduates have increasingly been recruited, providing significant scope to exercise degree level skills and knowledge (e.g. occupational therapists, quantity surveyors and management accountants). In the fourth category, 'niche graduate jobs', although the majority of people are non-graduates significant groups of occupations require degrees or provide scope to exercise degree level skills and knowledge (e.g. planning and quality control engineers, hotel and accommodation managers and nurses). Occupations not classified above are termed 'non-graduate occupations,' reflecting jobs where graduate level skills are inappropriate. This category was used to define over-education.

A repeated cross-sectional dataset from the years 1992-2010 of the UKLFS was constructed to give sufficient minority ethnic sample sizes. For the wage estimates, the dataset utilized the UKLFS wage sub-sample (1993-2010). Both samples were restricted to respondents holding $\mathrm{NVQ}^{1}$ level 4 or 5 qualifications. ${ }^{2}$ UK Census definitions of ethnicity were used although sample sizes necessitated a focus on larger minority ethnic populations and the combining of some ethnic groups (Bangladeshi and Pakistani respondents). Matching was based upon the two $^{3}$ closest matched members of the comparison group sample who were most comparable to a given member of the minority ethnic sample based on Mahalanobis distances and propensity scores ${ }^{4}$ (Rosenbaum and Rubin, 1983; Rubin, 1980; Sekhon, 2009). This matching was conducted on degree subject/type of higher level qualification (first degree, higher degree, nursing or teaching/other vocational qualification e.g. BTEC/NVQ), length of time in current job (tenure), number of hours worked per week, whether respondents had a partner $(1=$ yes, $0=$ no), youngest dependent child age, region, age and year. The LFS does not include a lifetime employment experience measure, although age and job tenure were included in the matching process. For unemployment estimates, tenure and working hours were excluded. Matching confers a number of advantages over alternative regression based methods (e.g. Oaxaca and Ransom, 1994). These latter methods as generally applied do not restrict estimates to individuals comparable in their characteristics, a situation which for current purposes risks mis-specifying estimates of ethnic penalties (regarding gender gaps, see both Frölich, 2007 and Nopo, 2009: 290).

\section{Results}

Table 2 gives the incidence of graduate level over-education for the minority ethnic and entire (i.e. not just matched) UK born white samples. Comparisons between these groups provide the 'raw' pre-matched 'ethnic differences' (as opposed to matched ethnic penalties) in over-education. Overall the representation of people with higher level qualifications in non-graduate occupations was greater for minority ethnic groups than for white UK born men and women. Black African and Pakistani/Bangladeshi women and men with graduate level qualifications were among the least likely to work in graduate jobs. Around 37.7 per cent of black African women and 36.4 per cent of Pakistani/Bangladeshi 
Table 2. SOC $(\mathrm{HE})$ graduate and non-graduate occupations by ethnic group

\begin{tabular}{|c|c|c|c|c|c|c|}
\hline & $\begin{array}{l}\text { White } \\
\text { UK born }\end{array}$ & $\begin{array}{l}\text { Black } \\
\text { Caribbean }\end{array}$ & $\begin{array}{l}\text { Black } \\
\text { African }\end{array}$ & Indian & $\begin{array}{l}\text { Pakistani/ } \\
\text { Bangladeshi }\end{array}$ & Chinese \\
\hline \multicolumn{7}{|l|}{ ALL } \\
\hline \multicolumn{7}{|l|}{ Men } \\
\hline Non-graduate occup. & - & 28.1 & 36.4 & 21.7 & 33.4 & 25.5 \\
\hline Base & & 538 & 1031 & 2459 & 944 & 448 \\
\hline \multicolumn{7}{|l|}{ Women } \\
\hline Non-graduate occup. & - & 25.9 & 37.7 & 28.7 & 36.4 & 28.7 \\
\hline Base & - & 1158 & 1003 & 1905 & 528 & 537 \\
\hline \multicolumn{7}{|l|}{ UK BORN } \\
\hline \multicolumn{7}{|l|}{ Men } \\
\hline Non-graduate occup. & 18.8 & 27.5 & 29.3 & 24.4 & 33.5 & 32.7 \\
\hline Base & 92080 & 342 & 198 & 819 & 376 & 101 \\
\hline \multicolumn{7}{|l|}{ Women } \\
\hline Non-graduate occup. & 24.0 & 30.2 & 38.6 & 31.0 & 39.2 & 27.9 \\
\hline Base & 88726 & 646 & 223 & 824 & 324 & 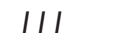 \\
\hline \multicolumn{7}{|l|}{ NON-UK BORN } \\
\hline \multicolumn{7}{|l|}{ Men } \\
\hline Non-graduate occup. & - & 29.1 & 38.1 & 20.4 & 33.3 & 23.3 \\
\hline Base & - & 196 & 833 & 1640 & 568 & 347 \\
\hline \multicolumn{7}{|l|}{ Women } \\
\hline Non-graduate occup. & - & 20.5 & 37.4 & 26.9 & 31.9 & 28.9 \\
\hline Base & - & $5 / 2$ & 780 & 1081 & 204 & 426 \\
\hline
\end{tabular}

Notes: Employed NVQ Level 4/5 holders, women 18-60 years old, men 18-65 years old, unweighted.

women with higher level qualifications worked in non-graduate occupations compared to 24 per cent of white UK born women. The equivalent figures for men were 36.4 per cent and 33.4 per cent respectively compared to 18.8 per cent of white UK born men. Based on raw differences, Indian men and women tended to have lower levels of overeducation although they were still more likely to be employed in non-graduate jobs than their white UK born counterparts. The representation of black Caribbean women graduates in non-graduate jobs was fairly similar to white UK born women (25.9\%). UK born white women nonetheless remained 5 per cent more likely than white UK born men to work in non-graduate occupations.

In addition to discrimination, labour market disadvantages such as poorer English language ability, less developed social networks or a lack of knowledge about the UK labour market and job application conventions are more concentrated among immigrant compared to native born minority ethnic men and women (Dustmann and Fabri, 2003; Fleischmann and Dronkers, 2010; Kogan, 2004). In the current study, however, the relationship between migration status and occupational attainment based on the raw prematched differences was mixed. UK born black Caribbean and Pakistani/Bangladeshi women with higher level qualifications were considerably more likely to work 
in non-graduate occupations than their non-UK born counterparts $(30.2 \%$ and $39.2 \%$ compared to $20.5 \%$ and $31.9 \%$ respectively). When the sample was restricted to the UK born, Chinese men were also among the most likely to be over-educated $(32.7 \%)$. For some ethnic groups, however, levels of over-education were higher among immigrant men and women. This was particularly the case for black African men where 38.1 per cent of those not born in the UK worked in non-graduate jobs compared to 29.3 per cent of the UK born.

The pattern of relative differences between ethnic groups remained fairly stable across the observation period with black African and Pakistani/Bangladeshi men and women and black Caribbean men consistently exhibiting the highest levels of over-education (Figure 1). With the exception of Indian women, who experienced a relative improvement in their representation in graduate jobs, a general upward trend in graduate overeducation was observed which was more pronounced for minority ethnic men and women. For example, the percentage of Chinese women with higher level qualifications working in non-graduate occupations increased from 17.3 per cent to 31.6 per cent between 1992-2005 and 2006-10 (14.3 percentage points) whereas Pakistani/ Bangladeshi men witnessed an increase from 27.7 per cent to 38.3 per cent (10.6 percentage points). This compared to an increase of around 2.7 percentage points and 2.5 percentage points for white UK born women and men respectively. Within the context of the expansion of higher education over the last two decades it would appear that the relative position of graduates from several minority ethnic groups has deteriorated. This could partly reflect compositional changes in graduate populations such as minority ethnic students disproportionately filling places at new universities rather than at traditional universities during the expansion of higher education.

The greater specialization in traditional graduate subjects among minority ethnic groups observed in other studies (Connor et al., 2004) was reflected in the type of graduate jobs undertaken (Table 3). Indian and Chinese men and women and Pakistani/ Bangladeshi women with NVQ level 4 or 5 qualifications were more likely to
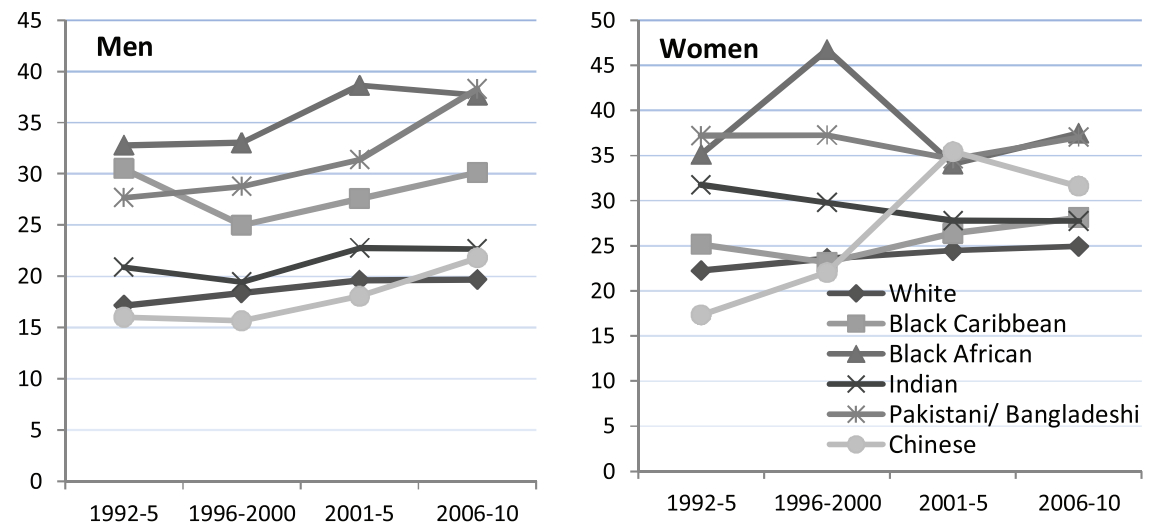

Figure I. Graduate SOC (HE) over-education by ethnic group (1992-5, 1996-2000, 200 I-5, 2006-10)

Note: UKLFS. Percentage of NVQ level 4/5 qualification holders in SOC(HE) non-graduate jobs. 
Table 3. SOC(HE) graduate occupation category by ethnic group

\begin{tabular}{|c|c|c|c|c|c|c|}
\hline & White & $\begin{array}{l}\text { Black } \\
\text { Caribbean }\end{array}$ & $\begin{array}{l}\text { Black } \\
\text { African }\end{array}$ & Indian & $\begin{array}{l}\text { Pakistani/ } \\
\text { Bangladeshi }\end{array}$ & Chinese \\
\hline \multicolumn{7}{|l|}{ Men } \\
\hline Traditional & 18.0 & 13.0 & 16.4 & 23.6 & 19.6 & 24.8 \\
\hline Modern & 17.6 & 15.4 & 13.2 & 19.1 & 15.8 & 17.0 \\
\hline New graduate & 20.0 & 17.1 & 13.1 & 15.5 & 13.1 & 14.1 \\
\hline Niche graduate & 25.7 & 26.4 & 21.0 & 20.1 & 18.1 & 18.8 \\
\hline $\begin{array}{l}\text { Non-graduate } \\
\text { occupation }\end{array}$ & 18.8 & 28.1 & 36.4 & 21.7 & 33.4 & 25.5 \\
\hline \multicolumn{7}{|l|}{ Women } \\
\hline Traditional & 16.5 & 9.2 & 9.5 & 20.9 & 21.6 & 19.0 \\
\hline Modern & 19.7 & 17.1 & 10.5 & 13.8 & 16.3 & 8.8 \\
\hline New graduate & 12.3 & 10.5 & 8.6 & 12.3 & 10.2 & 16.4 \\
\hline Niche graduate & 27.6 & 37.4 & 33.8 & 24.4 & 15.5 & 27.2 \\
\hline $\begin{array}{l}\text { Non-graduate } \\
\text { occupation }\end{array}$ & 24.0 & 25.9 & 37.7 & 28.7 & 36.4 & 28.7 \\
\hline
\end{tabular}

Notes: Employed NVQ Level 4/5 holders, UKLFS (1992-2010), women 18-60 years old, men I8-65 years old, unweighted.

concentrate in traditional graduate occupations than white British men and women. Around 24.8 per cent of Chinese men with higher level qualifications worked in traditional graduate occupations compared to 18 per cent of white UK born men. Black African women with higher level qualifications in contrast were poorly represented in traditional graduate jobs with only 9.5 per cent of those with such qualifications working in these occupations compared to 16.5 per cent of white UK born women. Their employment was instead concentrated in non-graduate and 'niche' occupations - the latter being the most heterogeneous SOC (HE) graduate occupation category where most jobs do not require a degree. Despite their better overall representation in graduate compared to nongraduate occupations, a similar finding held for black Caribbean women. These findings taken together are consistent with the high overall concentration of black women in nursing and other caring 'niche' professions (Bradley et al., 2007).

Table 4 presents the matching estimates of ethnic penalties in graduate level overeducation. The ATT here, taken as the ethnic penalty, denotes the difference between the proportion of a given minority ethnic group employed in a non-graduate occupation and the estimated proportion that would be expected to be so employed if they were members of the white UK born majority. For example, for black African UK born graduate men, an ATT of 0.12 indicates they were 12 per cent more over-represented in non-graduate jobs compared to equivalent matched white UK male graduates. Covariate balance summary statistics are presented in Table 5. These indicate the extent to which covariate matching reduces the difference between the values of covariates between comparator groups, facilitating 'like-with-like' comparisons.

Matching highlighted the varying effects compositional differences in observable characteristics play in shaping labour market outcomes. After matching, compared to the 
Table 4. Matched estimates: representation in SOC(HE) non-graduate occupations

\begin{tabular}{|c|c|c|c|c|c|c|c|}
\hline & $\begin{array}{l}\text { Raw } \\
\text { Diff. (\%) } \\
\text { All: }\end{array}$ & $\begin{array}{l}\text { Matched } \\
\text { Diff. (ATT) }\end{array}$ & s.e. & $\begin{array}{l}\text { Matched } \\
\text { Diff. TT) } \\
\text { UK Born: }\end{array}$ & s.e. & $\begin{array}{l}\text { Matched } \\
\text { Diff. (ATT) } \\
\text { Foreign } \\
\text { born: }\end{array}$ & s.e. \\
\hline \multicolumn{8}{|l|}{ Men } \\
\hline Black Caribbean & (9.3) & $0.06 * *$ & 0.02 & $0.04 \mathrm{~ns}$ & 0.03 & $0.11 * *$ & 0.04 \\
\hline Black African & $(17.6)$ & $0.20 * *$ & 0.02 & $0.12 * *$ & 0.04 & $0.23 * *$ & 0.02 \\
\hline Indian & $(2.9)$ & $0.07 * *$ & 0.01 & $0.06 * *$ & 0.02 & $0.08 * *$ & 0.01 \\
\hline $\begin{array}{l}\text { Pakistani/ } \\
\text { Bangladeshi }\end{array}$ & $(14.6)$ & $0.13 * *$ & 0.02 & $0.06 * *$ & 0.03 & $0.16 * *$ & 0.02 \\
\hline Chinese & (6.7) & $0.09 * *$ & 0.02 & $0.10 \mathrm{~ns}$ & 0.05 & $0.11 * *$ & 0.02 \\
\hline \multicolumn{8}{|l|}{ Women } \\
\hline Black Caribbean & (1.9) & $0.03 * *$ & 0.01 & $0.05 * *$ & 0.02 & $0.01 \mathrm{~ns}$ & 0.02 \\
\hline Black African & (13.7) & $0.15 * *$ & 0.02 & $0.17 * *$ & 0.04 & $0.15 * *$ & 0.02 \\
\hline Indian & $(4.7)$ & 0.07 ** & 0.01 & $0.05 * *$ & 0.02 & $0.09 * *$ & 0.01 \\
\hline $\begin{array}{l}\text { Pakistani/ } \\
\text { Bangladeshi }\end{array}$ & $(12.4)$ & $0.09 * *$ & 0.02 & $0.10 * *$ & 0.03 & $0.10 * *$ & 0.03 \\
\hline Chinese & $(4.7)$ & $0.10 * *$ & 0.02 & $0.06 \mathrm{~ns}$ & 0.04 & $0.10 * *$ & 0.02 \\
\hline
\end{tabular}

Notes: Employed NVQ Level 4/5 holders. UKLFS (1992-2010), unweighted. Raw \% difference indicates the difference between the percentage of a minority ethnic group who work in non-graduate occupations and the percentage of the UK-born white group (see Table 2). ATT is average treatment effect for the treated. $*_{p}<0.05, * *$ p. $<0.01$, ns $=$ not significant.

raw differences the penalties for some groups were larger whereas for others they remained similar or were smaller. For Indian and Chinese men and women in particular, the pre-matched raw estimates concealed the extent of over-representation in nongraduate occupations. Thus whereas the raw difference suggested an over-representation of just 2.9 per cent for Indian men, after matching this figure increased to 7 per cent. For black Caribbean men and Pakistani/Bangladeshi women in contrast the size of gap estimated was smaller following matching. The larger magnitude of the pre-matched ethnic differences witnessed for these groups was therefore attributable to observed human capital and demographic characteristics related to poorer labour market outcomes.

Despite the pre-matched differences suggesting a mixed picture regarding the relationship between immigration status and over-education, the relative position of foreign born compared to UK born men and women following matching was generally worse than suggested by the raw differences. For black African and Pakistani/Bangladeshi men ethnic penalties were particularly higher for foreign born men although this was not the case for black African and Pakistani/Bangladeshi women. Consequently, whereas the raw differences suggested foreign born Pakistani/Bangladeshi women fared better in their representation in graduate occupations than their UK born counterparts, matching revealed a similar penalty of around 10 per cent for both groups $($ ATT $=0.10, p<0.01)$. Despite black Caribbean women exhibiting similar levels of over-education to white women, black Caribbean men experienced greater over-education penalties than white 
Table 5. Covariate balance summary statistics

\begin{tabular}{llll}
\hline & $\begin{array}{l}\text { Before matching } \\
\text { Average std } \\
\text { mean difference }\end{array}$ & $\begin{array}{l}\text { After matching } \\
\text { Average std } \\
\text { mean difference }\end{array}$ & $\begin{array}{l}\text { After matching } \\
\text { No. t-tests } \mathrm{p} \\
<0.05\end{array}$ \\
\hline SOC(HE) & & 0.5 & $\begin{array}{l}\text { Each out of 2 16: } \\
\text { Black Caribbean }\end{array}$ \\
Black African & 8.9 & 0.1 & 23 \\
Indian & 8.2 & 0.1 & 27 \\
Pakistani/Bangladeshi & 2.5 & $<0.1$ & 25 \\
Chinese & 1.9 & $<0.1$ & 19 \\
Unemployment & 0.1 & & 12 \\
Black Caribbean & 8.8 & 0.3 & Each out of 204: \\
Black African & 8.5 & 0.2 & 20 \\
Indian & 3.4 & 0.1 & 20 \\
Pakistani/Bangladeshi & 2.8 & $<0.1$ & 19 \\
Chinese & 1.2 & $<0.1$ & 23 \\
Hourly wage rate & & & 4 \\
Black & 8.0 & 0.5 & 20 \\
Indian & 2.9 & $<0.1$ & 19 \\
Pakistani/Bangladeshi & 1.3 & 0.1 & 10 \\
Chinese & 0.9 & 0.2 & 4 \\
\hline
\end{tabular}

Notes: Std mean difference is the difference between the standardized mean covariate value for a specific minority ethnic and matched comparator group multiplied by 100 . Standardization uses the pooled standard deviation (see Rosenbaum and Rubin, 1985). After matching t-test indicates the number of mean differences for covariates that remained statistically significant between compared groups following matching. A smaller number indicates better matching.

men although this appeared largely due to penalties among non-UK born first generation immigrants.

Barriers to obtaining work matching qualification levels could also lead to longer job search or greater turnover, increasing levels of unemployment. Minority ethnic groups who were more poorly represented in graduate occupations also tended to have the highest levels of unemployment (Table 6). The size of the differences between the raw prematched unemployment gaps and matched ethnic penalty estimates were generally smaller though than for over-education (Table 7). This suggested that the raw unemployment gaps were more consistent with what would be expected based on observed human capital and demographic characteristics. Apart from black African men and black Caribbean women, unemployment penalties were most pronounced among non-UK born respondents with Pakistani/Bangladeshi foreign born men experiencing the largest penalty at 17 per cent $(\mathrm{ATT}=0.17, \mathrm{p}<0.01)$.

For the wage estimates, due to the smaller wage sub-sample the black Caribbean and black African groups were combined into a single category. Overall patterns of hourly wage rates (Table 8) were similar to those observed for patterns of over-education. Among men, black and Pakistani/Bangladeshi respondents exhibited the biggest wage 
Table 6. ILO unemployment (NVQ level 4/5 qualification holders)

\begin{tabular}{lcccccc}
\hline & White & $\begin{array}{l}\text { Black } \\
\text { Caribbean }\end{array}$ & $\begin{array}{l}\text { Black } \\
\text { African }\end{array}$ & Indian & $\begin{array}{l}\text { Pakistani/ } \\
\text { Bangladeshi }\end{array}$ & Chinese \\
\hline Men & & & & & & \\
Unemployed & 3.7 & 9.3 & 12.3 & 5.6 & 9.6 & 6.1 \\
Non-graduate job & 18.1 & 25.5 & 31.9 & 20.5 & 30.1 & 23.9 \\
Graduate job & 78.2 & 65.3 & 55.8 & 73.9 & 60.1 & 70.0 \\
Base & 95648 & 593 & 1175 & 2605 & 1046 & 477 \\
Women & 2.4 & 6.2 & 10.0 & 5.4 & 11.3 & 5.6 \\
Unemployed & 23.4 & 24.3 & 33.9 & 27.1 & 32.3 & 27.1 \\
Non-graduate job & 74.2 & 69.5 & 56.1 & 67.5 & 56.5 & 67.3 \\
Graduate job & 90922 & 1234 & 1115 & 2014 & 595 & 569 \\
Base & & & & & & \\
\hline
\end{tabular}

Notes: Economically active, NVQ Level 4/5 holders. UKLFS (I992-2010), unweighted.

Table 7. Matched estimates: ILO unemployment (NVQ level 4/5 qualification holders)

\begin{tabular}{|c|c|c|c|c|c|c|c|}
\hline & $\begin{array}{l}\text { Raw } \\
\text { Diff. (\%) }\end{array}$ & $\begin{array}{l}\text { Matched } \\
\text { Diff. (ATT) }\end{array}$ & s.e & $\begin{array}{l}\text { Matched } \\
\text { Diff. (ATT) }\end{array}$ & s.e & $\begin{array}{l}\text { Matched } \\
\text { Diff. (ATT) }\end{array}$ & s.e \\
\hline & \multicolumn{3}{|l|}{ All: } & \multicolumn{2}{|l|}{ UK born: } & \multicolumn{2}{|l|}{$\begin{array}{l}\text { Foreign } \\
\text { Born: }\end{array}$} \\
\hline \multicolumn{8}{|l|}{ Men } \\
\hline Black Caribbean & $(5.6)$ & $0.06 * *$ & 0.01 & $0.06 * *$ & 0.02 & $0.13 * *$ & 0.03 \\
\hline Black African & $(8.6)$ & $0.09 * *$ & 0.01 & $0.10 * *$ & 0.03 & $-1.91 \mathrm{~ns}$ & 1.55 \\
\hline Indian & $(1.9)$ & $0.03 * *$ & 0.01 & $0.03 * *$ & 0.01 & $0.08 * *$ & 0.01 \\
\hline Pakistani/Bangladeshi & $(5.9)$ & $0.07 * *$ & 0.01 & $0.07 * *$ & 0.02 & $0.17 * *$ & 0.02 \\
\hline Chinese & $(2.4)$ & $0.03 * *$ & 0.01 & $0.04 n s$ & 0.03 & $0.11 * *$ & 0.02 \\
\hline \multicolumn{8}{|l|}{ Women } \\
\hline Black Caribbean & (3.8) & $0.04 * *$ & 0.01 & $0.05 * *$ & 0.01 & $0.0 \mathrm{Ins}$ & 0.02 \\
\hline Black African & $(7.6)$ & $0.08 * *$ & 0.01 & $0.08 * *$ & 0.02 & $0.13 * *$ & 0.02 \\
\hline Indian & $(3.0)$ & $0.03 * *$ & 0.01 & $0.01 \mathrm{~ns}$ & 0.01 & $0.08 * *$ & 0.01 \\
\hline Pakistani/Bangladeshi & $(8.9)$ & $0.09 * *$ & 0.01 & $0.07 * *$ & 0.02 & $0.09 * *$ & 0.03 \\
\hline Chinese & $(3.2)$ & $0.03 * *$ & 0.01 & $0.0 \mathrm{lns}$ & 0.02 & $0.10 * *$ & 0.02 \\
\hline
\end{tabular}

Notes: Raw difference is the difference between pre-matched percentages (see Table 4). ATT is average treatment effect for the treated. $*$ p. $<0.05, * *$ p. $<0.01$, ns $=$ not significant.

penalties (Table 9). Notably, although the pre-matched wage gap and matched (ethnic penalty) estimates were similar for Pakistani/Bangladeshi men (-£3.89 and $-£ 3.61$ respectively) the pre-matched estimate considerably underestimated the wage penalties experienced by black men (- $£ 2.95$ compared to $-£ 5.89$ matched ethnic penalty). The matched wage penalty for Indian men in contrast was much smaller (-£0.54) and was not statistically significant. The pre-matched wage gap estimates nonetheless also concealed the wage penalties experienced by black women. After matching black women exhibited 
Table 8. Mean hourly wages rates (NVQ Level 4/5 holders)

\begin{tabular}{|c|c|c|c|c|c|c|c|c|c|c|}
\hline & \multicolumn{5}{|l|}{ MEN } & \multicolumn{5}{|l|}{ WOMEN } \\
\hline & $\begin{array}{l}\text { White } \\
\text { (UK) }\end{array}$ & Black & Indian & $\begin{array}{l}\text { Pakistani/ } \\
\text { Bangladeshi }\end{array}$ & Chinese & $\begin{array}{l}\text { White } \\
\text { (UK) }\end{array}$ & Black & Indian & $\begin{array}{l}\text { Pakistani/ } \\
\text { Bangladeshi }\end{array}$ & Chinese \\
\hline Mean & 16.43 & 13.48 & 16.34 & 12.54 & 14.28 & 12.73 & 12.15 & 13.39 & $\mid 1.31$ & 13.23 \\
\hline$n=$ & 18400 & 324 & 545 & 216 & 88 & 19453 & 464 & 443 & 140 & 100 \\
\hline
\end{tabular}

Notes: Employed, UKLFS 1993-2010.Adjusted to 2005 RPI prices.

Table 9. Matched estimates: hourly wage rates (NVQ level 4/5 qualification holders)

\begin{tabular}{|c|c|c|c|c|c|}
\hline $\begin{array}{l}\text { Raw } \\
\text { Diff. }\end{array}$ & $\begin{array}{l}\text { Matched } \\
\text { Diff. (ATT) }\end{array}$ & s.e & $\begin{array}{l}\text { Matched } \\
\text { Diff. (ATT) }\end{array}$ & s.e & $\begin{array}{l}\text { Matched } \\
\text { Diff. (ATT) }\end{array}$ \\
\hline All: & & & UK Born: & & Foreign Born \\
\hline
\end{tabular}

\begin{tabular}{llllllll}
\hline Men & & & & & & & \\
Black African/ Caribbean & $(-2.95)$ & $-5.89 * *$ & 0.64 & $-3.86^{* *}$ & 1.10 & $-6.8 I^{* *}$ & 0.77 \\
Indian & $(-0.09)$ & $-0.54 \mathrm{~ns}$ & 0.45 & $-0.36 \mathrm{~ns}$ & 0.66 & $-0.68 \mathrm{~ns}$ & $0.6 \mathrm{I}$ \\
Pakistani/Bangladeshi & $(-3.89)$ & $-3.6 I^{* *}$ & 0.59 & $-3.30^{* *}$ & 0.67 & $-4.24^{* *}$ & 0.93 \\
Chinese & $(-2.15)$ & $-3.65^{* *}$ & 1.11 & $(-)$ & $(-)$ & $-4.24^{* *}$ & 1.28 \\
Women & & & & & & & \\
BlackAfrican/ Caribbean & $(-0.58)$ & $-2.46 * *$ & 0.34 & $-2.08^{* *}$ & 0.54 & $-2.92^{* *}$ & 0.42 \\
Indian & $(+0.66)$ & $-0.29 \mathrm{~ns}$ & 0.40 & $-0.04 \mathrm{~ns}$ & 0.48 & $-0.59 \mathrm{~ns}$ & 0.58 \\
Pakistani/Bangladeshi & $(-1.42)$ & $-0.86 \mathrm{~ns}$ & 0.66 & $-0.14 \mathrm{~ns}$ & 0.97 & $-2.19 * *$ & 0.93 \\
Chinese & $(0.50)$ & $+0.63 \mathrm{~ns}$ & 0.81 & $(-)$ & $(-)$ & $+0.1 \mathrm{~ns}$ & 0.92 \\
\hline
\end{tabular}

Notes: Employed, UKLFS 1993-2010. Raw difference is the difference between pre-matched mean hourly wage rates (see Table 6). Real wages (2005 RPI prices). Base $=$ white UK born. $*_{\mathrm{p}}<0.05$, $*^{*} \mathrm{p}<0.0 \mathrm{I}$, ns $=$ not significant. (-)Chinese UK born estimates suppressed due to small cell frequency.

a mean hourly wage rate of around $£ 2.46$ less than white women, compared to a raw difference of $-£ 0.58$. Non-UK born Pakistani/Bangladeshi women similarly exhibited a wage penalty of around $£ 2.19$ per hour based on matched comparisons although a similar penalty was not observed for those born in the UK. Based on their observed human capital and demographic characteristics a substantial proportion of minority ethnic men and women with higher level qualifications appear underpaid compared to their white UK born counterparts.

\section{Discussion and conclusions}

Although past research suggests education for many minority ethnic men and women has provided a route to better employment or higher occupational status (Dale et al., 2002; Modood, 2004; Platt, 2007) the current findings indicate higher level qualifications still do not appear to provide a panacea or facilitate an equalization of labour market outcomes to those of comparably educated white UK born men and women. Graduate level 
ethnic penalties were witnessed for several minority ethnic groups across labour market outcomes. Despite some groups such as Indian and Chinese men and women appearing to have comparatively favourable labour market outcomes (Khattab, 2009), matched contrasts to comparably educated white UK born men and women revealed labour market penalties concealed in simple overall comparisons. The extent of wage penalties experienced by black African and black Caribbean men and women were similarly only exposed through matching. Unemployment also precludes the risk of being classified as over-educated to a greater extent for some ethnic groups, warning against solely focusing on employed populations when examining ethnic penalties.

An important question remaining is why after controlling for compositional differences in individual characteristics ethnic penalties varied between minority ethnic groups? Although more fine-grained aspects of qualification heterogeneity between minority ethnic groups such as the greater concentration of black African men and women in new universities (Connor et al., 2004) could contribute to differences in labour market penalties, differential levels of discrimination towards specific minority ethnic groups relating to varying prejudices or stereotypes are a further likely factor (Modood, 1997). Furthermore, qualification heterogeneity based explanations of overeducation as currently formulated, focusing on individual ability and educational investment decisions remain problematic for explaining ethnic differences in overeducation. Broader sociological literatures discussed earlier highlight how patterns of educational attainment are partly shaped by social advantage and disadvantage, related not only to ethnicity, but other important dimensions such as social class and gender. Although vocational differences between ethnic groups may partly reflect historical patterns of geographical and occupational settlement, ethnic or racial stereotyping and workplace cultures related to both gender and ethnicity can place significant barriers to accessing professions, career advancement, or moving occupations (Bolton and Muzio, 2008; Bradley et al., 2007; Stainback et al., 2010). Notably, given degree subject was controlled for in the current study, labour market penalties also persisted after accounting for an aspect of vocational 'choice' or preferences emphasized in qualification heterogeneity accounts (Chevalier, 2002, 2003; Machin and Puhani, 2003; Ortiz and Kucel, 2008).

Ethnic penalties as currently measured, however, still only tell part of the story of the disadvantage experienced by minority ethnic groups, given they do not fully capture the influence of pre-labour market disadvantages (Heath and Cheung, 2006: 19). Although the effects of such factors may be harder to identify in labour market data, they are implicit in the distributions of characteristics such as educational attainment between ethnic groups. Graduate level ethnic employment penalties nonetheless remain of concern to the employment prospects of minority ethnic graduates, as well as to broader issues of social equality and widening access to education, given they may reflect the cumulative effects of disadvantage not just within the labour market but in the wider education system and society.

\section{Acknowledgement}

I would like to thank ONS and ESDS Government for making the UKLFS data available and Prof. Angela Dale for comments on an earlier version of this article. 


\section{Notes}

1 A NVQ framework variable harmonized for qualification changes over time was created using Economic and Social Data Service (ESDS) Government guidance (see http://www. esds.ac.uk/government/dv/).

2 Overseas qualifications where no UK equivalent is identified are classified as 'other' in the UKLFS (NVQ level 1).

3 The results were robust to the number of matches used, matching algorithm and bias adjustment (see Abadie and Imbens, 2006).

4 Propensity scores used probit regression predicted probabilities predicting membership to a given minority ethnic group using the matching predictors.

\section{References}

Abadie A and Imbens G (2006) Large sample properties of matching estimators for average treatment effects. Econometrica 74(1): 235-67.

Alpin C, Shackelton J and Walsh S (1998) Over- and under-education in the UK graduate labour market. Studies in Higher Education 23(1): 17-30.

Archer L (2011) Constructing minority ethnic middle-class identity: an exploratory study with parents, pupils and young professionals. Sociology 45(1): 134-51.

Barnard H and Turner C (2011) Poverty and Ethnicity: A Review of Evidence. York: JRF.

Battu H and Sloane PJ (2002) To what extent are ethnic minorities in Britain over-educated? International Journal of Manpower 23(3): 192-208.

Battu H and Sloane PJ (2004) Over-education and ethnic minorities in Britain. The Manchester School 72(4): 535-59.

Battu H, Belfield CR and Sloane PJ (1999) Over-education among graduates: a cohort view. Education Economics 7: 21-38.

Behtoui A and Neergaard A (2010) Social capital and wage disadvantages among immigrant workers. Work, Employment and Society 24(4): 761-79.

Berthoud R (2000) Ethnic employment penalties in Britain. Journal of Ethnic and Migration Studies 26(3): 389-416.

Blackaby DH, Leslie DG, Murphy PD and O'Leary NC (1999) Unemployment among Britain's ethnic minorities. The Manchester School 67(1): 1-20.

Blackaby DH, Leslie DG, Murphy PD and O'Leary NC (2002) White/ethnic minority earnings and employment differentials in Britain. Oxford Economic Papers 54(2): 270.

Blau FD and Kahn LM (2007) The gender pay gap: have women gone as far as they can? The Academy of Management Perspectives 21(1): 7-23.

Boliver V (2011) Expansion, differentiation, and the persistence of social class inequalities in British higher education. Higher Education 61: 229-42.

Bolton S and Muzio D (2008) The paradoxical processes of feminization in the professions: the case of established, aspiring and semi-professions. Work, Employment and Society 22(2): 281-99.

Botcherby S (2006) Pakistani, Bangladeshi and Black Caribbean Women and Employment Survey: Aspirations, Experiences and Choices. Manchester: Equal Opportunities Commission.

Bradley H and Healy G (2008) Ethnicity and Gender at Work: Inequalities, Careers, and Employment Relations. Basingstoke: Macmillan Palgrave.

Bradley H, Healy G, Forson C and Kaul P (2007) Workplace Cultures: What Does and Does Not Work, Report for the Equal Opportunities Commission. Manchester: EOC.

Browne I and Misra J (2003) The intersection of gender and race in the labor market. Annual Review of Sociology 29: 487-513. 
Brynin M (2002) Overqualification in employment. Work, Employment and Society 16(4): 637-54.

Burris V (2005) Overeducation: then and now. Work and Occupations 32: 319-21.

Carter B and Virdee S (2008) Racism and the sociological imagination. The British Journal of Sociology 59(4): 661-79.

Castilla EJ (2008) Gender, race, and meritocracy in organizational careers. American Journal of Sociology 113(6): 1479-1526.

Chevalier A (2002) Education, motivation and pay of UK graduates: is it different for girls? European Journal of Education 37: 347-70.

Chevalier A (2003) Measuring over-education. Economica 70(3): 509-31.

Chiswick BR and Miller PW (2010) Educational mismatch. In: Chiswick B (ed.) High-Skilled Immigration in a Global Labor Market. Washington, DC: A.E.I Press, 117-54.

Clark K and Drinkwater S (2007) Dynamics and Diversity: Ethnic Minorities in the Labour Market. Bristol: The Policy Press.

Collins PH (2004) Learning from the outsider within: the sociological significance of black feminist thought. In: Harding S (ed.) The Feminist Standpoint Theory Reader. London: Routledge, $103-27$.

Connor H, Tyers C, Modood T and Hillage J (2004) Why the Difference? A Closer Look at Higher Education Minority Ethnic Students and Graduates, DfES Research Report RR552. London: CDS.

Cooke L (2007) 'Husband's career first': renegotiating career and family commitment among migrant Chinese academic couples in Britain. Work, Employment and Society 21(1): 47-65.

Dale A, Shaheen V, Kalra and Fieldhouse E (2002) Labour market prospects for Pakistani and Bangladeshi women. Work, Employment and Society 16(1): 942-68.

Dale A, Lindley J, Dex S and Rafferty AL (2008) Ethnic differences in women's labour market activity. In: Scott J et al. (eds) Women and Employment: Changing Lives and New Challenges. Oxford: Oxford University Press, 81-106.

Department for Education and Skills (2006) Ethnicity and education. London: DfES.

Dolton P and Silles M (2001) Over-Education in the Graduate Labour Market. LSE Discussion Paper 9. London: Centre for the Economics of Education, LSE.

Dustmann C and Fabbri F (2003) Language proficiency and labour market performance of immigrants in the UK. The Economic Journal 113(489): 695-717.

Elias P and Purcell K (2004) SOC (HE): A Classification of Occupations for Studying the Graduate Labour Market, Researching Graduate Careers Seven Years On Research Paper 6. Coventry: University of Warwick Institute for Employment Research.

Fleischmann F and Dronkers J (2010) Unemployment among immigrants in European labour markets: an analysis of origin and destination effects. Work, Employment and Society 24(2): $337-54$.

Freeman RB (1976) The Overeducated American. New York, NY: Academic Press.

Frölich M (2007) Propensity score matching without conditional independence assumption with an application to the gender wage gap in the United Kingdom. The Econometrics Journal 10(2): 359-407.

Garcia-Espejo I (2005) Educational-skill matches and labour achievements among graduates in Spain. European Sociological Review 22(2): 141-56.

Green F and McIntosh S (2007) Is there a genuine under-utilization of skills amongst the overqualified? Applied Economics 49: 427-39.

Green C, Kler P and Leeves G (2007) Immigrant overeducation: evidence from recent arrivals to Australia. Economics of Education Review 26(4): 420-32.

Grimshaw D and Rubery J (2007) Undervaluing Women's Work. Manchester: Equal Opportunities Commission. 
Hartog J (2000) Overeducation and earnings: where are we, where should we go? Economics of Education Review 19(2): 131-47.

Heath A and Cheung SY (2006) Ethnic Penalties in the Labour Market: Employers and Discrimination, DWP Research Report 341. London: CDS.

Johnston R, Sirkeci I, Khattab N and Modood T (2010) Ethno-religious categories and measuring occupational attainment in relation to education in England and Wales: a multilevel analysis. Environment and Planning A 42(3): 578-91.

Khattab N (2009) Ethno-religious background as a determinant of educational and occupational attainment in Britain. Sociology 43(2): 304.

Kirton G and Green A (2010) The Dynamics of Managing Diversity: A Critical Approach. Oxford: Butterworth-Heinemann.

Kogan I (2004) Last hired, first fired? The unemployment dynamics of male immigrants in Germany. European Sociological Review 20(5): 445-61.

Leicht KT (2008) Broken down by race and gender? Sociological explanations of new sources of earnings inequality. Annual Review of Sociology 34: 237-55.

Lindley J (2009) The over-education of UK immigrants and minority ethnic groups: evidence from the labour force survey. Economics of Education Review 28(1): 80-89.

Longhi S and Platt L (2008) Pay Gaps across Equalities Areas. Manchester: EHRC.

McGinnity F and Lunn D (2011) Measuring discrimination facing ethnic minority job applicants: an Irish experiment. Work, Employment and Society 25(4): 693-708.

Machin S and Puhani PA (2003) Subject of degree and the gender wage differential: evidence from the UK and Germany. Economics Letters 79(3): 393-400.

Modood T (1997) Difference, cultural racism and anti-racism. In: Werbner P and Modood T (eds) Debating Cultural Hybridity. London: Zed Books, 251-78.

Modood T (2004) Capitals, ethnic identity and educational qualifications. Cultural Trends 13(2): $87-105$.

Nielsen CP (2011) Immigrant over-education: evidence from Denmark. Journal of Population Economics 24(2): 499-520.

Ñopo H (2008) Matching as a tool to decompose wage gaps. The Review of Economics and Statistics 90(2): 290-99.

Oaxaca R and Ransom MR (1994) On discrimination and the decomposition of wage differentials. Journal of Econometrics 61: 5-21.

Olsen WK and Walby S (2004) Modeling Gender Pay Gaps, Working Paper 17, Equal Opportunities Commission, Manchester, UK.

Ortiz L (2010) Not the right job, but a secure one. Work, Employment and Society 24(1): 47-64.

Ortiz L and Kucel A (2008) Do fields of study matter for over-education? International Journal of Comparative Sociology 49: 305-27.

Platt L (2007) Poverty and Ethnicity in the UK. Bristol: Policy Press.

Purcell K, Elias P and Atfield G (2009) Analysing the Relationship between Participation and Educational and Career Development Patterns and Outcomes, Futuretrack Working Paper 1, IER/HECSU, University of Warwick, Coventry, UK.

Riach PA and Rich J (2002) Field experiments of discrimination in the market place. The Economic Journal 112: 480-518.

Richardson JTE (2008) The attainment of ethnic minority students in UK higher education. Studies in Higher Education 33(1): 33-48.

Rosenbaum P and Rubin D (1983) The central role of the propensity score in observational studies for causal effects. Biometrika 70(1): 41-55.

Rosenbaum P and Rubin D (1985) Constructing a control group using multivariate matched sampling methods that incorporate the propensity score. The American Statistician 39(1): 33-8. 
Rothon C (2008) Women, men and social class revisited: an assessment of the utility of a 'combined' schema in the context of minority ethnic educational achievement in Britain. Sociology 42(4): 691-708.

Rubin D (1980) Bias reduction using Mahalanobis-metric matching. Biometrics 36(2): 293-98.

Sekhon J (2009) Opiates for the matches: matching methods for causal inference. Annual Review of Political Science 12: 487-508.

Sloane P, Battu B and Seaman PP (1999) Overeducation, undereducation and the British labour market. Applied Economics 31: 1437-53.

Smith RA (2002) Race, gender, and authority in the workplace: theory and research. Annual Review of Sociology 28: 509-42.

Stainback K, Tomaskovic-Devey D and Skaggs S (2010) Organizational approaches to inequality: inertia, relative power, and environments. Sociology 36(1): 225.

Strand S (2011) The limits of social class in explaining ethnic gaps in educational attainment. British Educational Research Journal 37(2): 197-229.

Tsang MC and Levin HM (1985) The economics of overeducation. Economics of Education Review 4(2): 93-104.

Vaisey S (2006) Education and its discontents: overqualification in America, 1972-2002. Social Forces 85(2): 835-64.

Verhaeghe P, Li Y and Van de Putte B (2012) Socio-economic and ethnic inequalities in social capital from the family among labour market entrants. European Sociological Review published online March 15 2012, doi: 10.1093/esr/jcs047.

Walby S, Armstrong J and Strid S (2012) Intersectionality: multiple inequalities in social theory. Sociology 46(2): 224-24.

Wilton N (2011) Do employability skills really matter in the UK graduate labour market? The case of business and management graduates. Work, Employment and Society 25(1): 85-100.

Yeandle S, Stiell B and Buckner L (2006) Ethnic Minority Women and Access to the Labour Market: Synthesis Report. Sheffield: Sheffield Hallam University.

Anthony Rafferty is Lecturer in Employment Studies attached to the European Work and Employment Research Centre (EWERC) and the Fairness at Work (FaW) Research Centre at Manchester Business School, University of Manchester, UK.

Date submitted January 2011

Date accepted May 2012 